\title{
ЕТНОГРАФІЧНІ ДОСЛІДЖЕННЯ ЦЕНТРАЛЬНОЇ УКРАЇНИ ПОЛЬСЬКИМИ ВЧЕНИМИ У ХІХ СТ.
}

\begin{abstract}
Анотація. У статті проаналізовано етнографічні дослідження Центральної України польськими вченими, письменниками та громадськими діячами у XIX ст. Здійснено загальний огляд праць дослідників, які зробили найбільший внесок у вивчення етнографічних особливостей Центральної України. Особлива увага звертаеться на фольклористичні дослідження та публікації текстів народних пісень. Дотримуючись хронологічного принципу періодизації, виокремлено конкретні здобутки польських вчених у дослідженні етнографії українців. Встановлено, що польськими дослідниками зібрано та опубліковано великий масив першоджерельного фольклорного і етнографрічного матеріалу, що й досі зберігає свое важливе значення для науки про усну традиційну культуру українців.
\end{abstract}

Ключові слова: Уманщина, етнографія, Центральна Україна, фольклористичні дослідження, польські етнографи, Адам Чарноцький, Северин Гощинський, Едвард Руліковський.

\section{Opatskyi Ihor \\ Pavlo Tychyna Uman State Pedagogical University}

\section{ETHNOGRAPHIC STUDIES OF CENTRAL UKRAINE BY POLISH SCIENTISTS IN THE $19^{\text {th }}$ CENTURY}

Summary. The article analyses ethnographic studies of the population of Central Ukraine by Polish scientists, writers and public figures in the $19^{\text {th }}$ century. A general review of the works of researchers who greatly contributed to the study of ethnographic features of Central Ukraine have been made. It is noted that in the $19^{\text {th }}$ century, under the influence of the ideas of Romanticism, an impetus was given to the study of people history, their language and customs, when a large number of Polish scholars were fascinated by the Ukrainian past. Adam Charnotsky, known under the pseudonym Zorian Dolengo-Khodakovsky, made a great contribution to the ethnographic study of the Ukrainians. In total, he recorded 12,000 folk songs that was the largest collection at that time in Slavic folklore. It has been investigated that representatives of the «Ukrainian school» of Polish literature, in particular Severyn Hoszczynski, addressed Ukrainian historical themes, descriptions of life, nature, and folklore. His work «Kanivskyi Zamok» described an organic embodiment of folk demonology, beliefs, features of the celebration of Ivan Kupalo holiday, and ethnographic information about the Ukrainians. The works of art of the «Ukrainian school» of Polish literature are not full-fledged ethnographic studies. However, written with the use of folklore material and descriptions of the life of the Ukrainians, they contributed to the growing interest of Polish researchers in Ukrainian ethnography. Ukrainian folk medicine has become the subject of scientific interest of the Polish physician Julian Talko-Grintsevich. His work «Essays on Folk Medicine of Southern Russia» uses more than three hundred samples of Ukrainian magical and sacred folklore, dominated by orders, sayings, spells, as well as folklore prayers. Among the active collectors of ethnographic material from the territory of Central Ukraine, researchers single out the name of Jozefa Moszynska. She collected customs and rituals of the population of Bila Tserkva, Tarashchansky and Vasylkiv districts of Kyiv region. Thus, Polish researchers have collected and published a large array of original folklore and ethnographic material. This material still retains its importance for the science of oral traditional culture of Ukrainians.

Keywords: Uman region, ethnography, Central Ukraine, folklore research, Polish ethnographers, Adam Charnotsky, Severin Goshchynsky, Edward Rulikovsky.

Постановка проблеми. Українсько-польські взаємини в історичній ретроспективі розвивалися по-різному: від ефрективної співпраці до відвертого антагонізму і навпаки. Різне трактування історичного минулого, суспільнополітичні виклики, що стояли перед двома народами, а разом з тим і значна частина спільної історії, переплетених родинних доль сприяли тому, що українці і поляки досить часто переходили від конфллікту до компромісу, а потім і до взаємодії. У XIX ст., під впливом ідей романтизму, який піднімав на щит ідею національної самобутності народів, давав імпульс до вивчення історії народу, його мови та звичаїв, значна кількість польських вчених захопилася українською минувшиною. Вони здійснювали експедиції українськими селами, проводили археологічні та етнографічні дослідження українських регіонів. Більшість польських дослідників вивчали українські Карпати, Волинь та Полісся. Територія Центральної України хоча й була в полі уваги польських дослідників, однак кількість досліджень була значно меншою в порівнянні із дослідженнями Західної України. До Центральної України відносимо території, що входили до складу української козацької держави - Гетьманщини та охоплювали землі Наддніпрянщини, Брацлавщини та Чернігово-Сіверщини. В сьогоднішньому адміністративно-територіальному поділі більшість цих земель входять до складу шести областей: Київської, Кіровоградської, Черкаської, Вінницької, Полтавської і Чернігівської.

Аналіз останніх досліджень і публікацій. Однією з перших спроб періодизації етно-

\footnotetext{
${ }^{1}$ ORCID: https://orcid.org/0000-0002-6786-3295
} 
графрічних досліджень Західної України є стаття I. Франка «Огляд праць над етнографрією Галичини в XIX в.» [11]. Не зважаючи на те, що праця присвячена дослідженню культури і побуту українщів Галичини, у ній I. Франко вказуе на внесок польських етнографрів у дослідження українського фольклору та етнографіiі. Етнограф, голова Етнографрічної комісії Наукового товариства імені Шевченка В. Гнатюк у численних оглядах праць польських етнографрічних видань та рецензіях на праці польських дослідників, котрі публікував в основному на сторінках «Записок Наукового товариства імені Шевченка», детально висвітлював україно-польські етнографічні взаємини та внесок польських дослідників у вивчення української етнографрії [8]. Ірунтовний аналіз українопольських наукових зв'язків у галузі етнології, питання україністики у дослідженнях провідних польських вчених та наукових товариств у XIX ст. здійснено етнографом 3. Болтарович у монографрiі «Україна в дослідженнях польських етнографів XIX ст.» [2]. Проаналізувавши зазначені та інші праці, перейдемо до ознайомлення 3 внеском польських дослідників у етнографрічне вивчення Центральної України.

Метою запропонованої статті е з'ясування внеску польських вчених, письменників та громадських діячів у фольклорно-етнографічні дослідження України.

Виклад основного матеріалу. Польський дослідник Францішик Ксаверій Гіжицький (1786-1850) був добре ознайомлений з традиціями українського народу, адже сам народився на Волині. У 1810 р. опубліковано його дослідження «Rys Ukrainy Zachodniej». До Західної України автор відносив також повіти між Дніпром і Дністром, які раніше входили до складу Брацлавського воєводства та південної частини Київського. Цитуючи інших авторів, які описували українські території, автор оминае складні події 1768 р., аби не посилювати польсько-український антагонізм. Дослідник підкреслюе риси характеру українців: відвагу і мужність у чоловіків та скромність і лагідність у жінок [2, с. 22]. Хоча у праці тенденційно висвітлено ряд питань щодо походження українців, не завжди подано достовірні відомості про український народ, однак вона має велику цінність як одна 3 перших спроб вивчення українства польськими етнографами.

Великий внесок у етнографічне дослідження українського народу здійснив Адам Чарноцький, відомий під псевдонімом Зоріан ДоленгоХодаковський (1784-1825). Народився у сім'ї збіднілого шляхтича у Мінській губернії (Білорусь). 1800 р. закінчив Слуцьке повітове училище, a 1805 р. успішно склав іспит з юриспруденції. У 1809 р. за висловлені в приватному листі думки про підтримку Наполеона та його армії був заарештований та засланий на військову муштру до Омська. 1811 р. у Бобруйську імітував втоплення, втік до Варшави та вступив до французької армії. Після поразки Наполеона назавжди змінив свое справжне ім'я на Зоріан Доленга-Ходаковський, під яким у ввійшов у історію слов'янознавства. 31813 р. дослідник переїздить до Волині, де працював бібліотекарем Кременецького ліцею i розпочав свої подорожі українськими та білоруськими землями, під час яких записував фоль- клор. У 1817-1818 рр. подорожував Галичиною і продовжив записувати народні пісні та збирати старожитності. У 1819 р. близько трьох тижнів вивчав пам'ятки старовини у Киеві, подорожував іншими населеними пунктами Центральної України та збирав і записував народні пісні, казки, повір'я, загадки, обряди, звичаї. Загалом ним було записано 12 тисяч народних пісень, з них на території Правобережжя й Західної України понад 2 тисячі народних пісень - найбільше на той час зібрання в слов'янській фольклористиці [5]. Подорожуючи українськими та білоруськими територіями вчений опрацьовував церковні архіви, описував городища та кургани, записував фольклор. До багатьох записів дослідник додавав опис обрядів, якими супроводжувалися записані пісні, зазначав місцевість запису. До речі, фріксація місця запису фольклорного матеріалу в той час майже не застосовувалася збирачами старовини, що додае особливої наукової цінності записам Доленги-Чарноцького. Частину зібраних 3. Доленгою-Чарноцьким записів придбав М. Максимович, інша частина збереглися в архіві Осипа Бодянського, ще частина спадщини перебувала у власності бібліотеки Наукового товариства імені Шевченка, де нею послуговувався Іван Франко [7, с. 425]. Зібрані та збережені уснословесні і матеріальні пам'ятки 3. ДоленгоХодаковський використав при написанні праці про етногенез слов'ян «O Słowiańszczyźnie pred chrześciaństwem», яка є важливим джерелом 3 давньої слов'янської історії та культури.

Дослідник ставив перед собою завдання: пройти Русь в 4-х напрямах і оглянути місця, від яких походять місцеві назви слов'ян; вивчити народні говори та різниці між ними; виявити особливості в одязі, будові житла, сільськогосподарських знаряддях; дослідити народну термінологію різних явищ природи; описати давні весільні обряди, ігри та пісні; збирати писемні джерела, монети та старожитності [2, с. 27]. Раптова смерть дослідника у 1825 р. не дала можливості повною мірою зреалізувати означену програму.

До української історичної тематики, описів побуту і природи, фольклору зверталися представники «української школи» польської літератури. Одним із чільних представників цього романтичного напряму польської літератури був Северин Гощинський (1801-1876). Народився майбутній письменник в с. Іллінці на Київщині, освіту здобув у гімназії василіанського монастиря м. Умань (1815/16-1819 рр.). Навчаючись в Умані поет пройнявся темою Коліївщини. Під час літніх канікул їздив до Корсуня, де оглянув руїни стародавнього замку. У 1824 р. в Умані С. Гощинський написав «Ніч у Софіiівці» та задумав написання "Канівського замку» - поеми про події Коліївщини. Для її створення поет подорожував місцями подій, використав спогади ще живих сучасників Коліївщини та втрачені на сьогодні тексти спогадів учасників гайдамацького руху, збирав фольклор. У 1828 р. поему було видано у Варшаві окремою книжечкою. На відміну від історичних та художніх праць попередників у Гощинського повстанці не оцінювалися негативно, вони відповідали жорстокістю на жорстокість. У творі знайшла органічне втілення народна демонологія, повір'я пов'язані з «чорта- 
ми», «опирями», «літавцями», «відьмами» та ін., особливості відзначення свята Івана Купайла. Твір здобув значний розголос серед польського суспільства та активізував обговорення польсько-українських взаемин [4].

Ще один представник «української школи» польської літератури Маврицій Гославський (1802-1834) у 1826 р. опублікував поему «Поділля», в якій торкнувся питання побуту та дозвілля українщів. Аналізуючи творчість М. Гославського Р. Кирчів відзначив: “... не лише краса подільської природи полонила Гославського. На нього мали сильний вплив численні історичні пам'ятки Поділля. Гославському 3 дитинства був близький побут українського села, його життя, багата усна словесність. Він, як сам відзначав не раз, полюбив український народ, його пісні і легенди. Тому не дивно, що край дитинства і молодості, мрій і прагнень поета глибоко увійшов в його творчість, надав їй тієї характерної прикмети, завдяки якій історики літератури назвали Гославського «співцем Поділля"» [9]. В поемі «Поділля» знайшли відображення українські народні пісні, зібраний поетом етнографрічний матеріал.

Художні твори представників «української школи» польської літератури не є повноцінними етнографічними дослідженнями. Однак написані 3 використанням фольклорного матеріалу та 3 описами побуту українського народу вони сприяли зростанню інтересу польських дослідників до української етнографії.

Ще один 3 представників «української школи» в польській літературі Міхал Грабовський (1804-1863), який спільно 3 С. Гощинським та Б. Залеським навчався в Умані, перейшов від аматорського зацікавлення українською минувшиною до наукового осмислення історичного минулого українського народу. Оселившись 31831 р. в родовому помісті на Черкащині профессійно займається дослідженням історії, літературною критикою та публіцистикою. Публікуе повісті з українського життя «Коліївщина і степи» (1838), «Станція Гуляйпільська» (1840), «Оповідання курінного» та ін. Найвідомішими історичними працями стали "Джерела до польської історії (1843) та «Україна давня і теперішня» (1850). Багато місця в творчості М. Грабовського відведено описам народних звичаїв та вірувань. Зокрема, він детально описує хрестини, звичай кумівства та фрункції хрещених батьків, описуе українські вечорниці. Переповідав на сторінках творів і народні повір'я про надприродні сили, значення появи комети, небіжчиків, які часто з'являлися рідним тощо [2, с. 57].

Зенон Фіш (псевдонім Тадуеш Падалиця) (1820-1870) відомий польський письменник та публіцист, який особливу увагу приділяв польсько-українським взаєминам у минулому та сучасних йому. Дитячі та юнацькі роки провів на Київщині. Описував подорожні враження з Києва, Корсуня, Чигирина, Черкас, Сміли, Гуляйполя. Відстоював культуртрегерську роль польської шляхти в Україні. У його творах збережено цінні етнографічні матеріали 3 життя українців. На основі зібраного фольклорного матеріалу описував розваги молоді у свята, характеризував святковий дівочий одяг, цікавився дослідженням ярмарків, показав особливості планування селищ та будівництва житла. Залишив цікаві відомості про чумаків, описав їхне походження, побут та заняття [2, с. 61].

Едвард Руліковський (1825-1900) народився в родині шляхтича на Київщині, спочатку здобув домашню освіту, а потім продовжив навчання у Парижі та Сорбоні. Після повернення до України в Липовці познайомився зі збирачем старовини Костянтином Свідзінським і під впливом цього знайомства захопився дослідженням української історії та етнографії. Результатом цього захоплення стала монографрія «Опис Васильківського повіту з точки зору історії, звичаїв, статистики» (1853), котра написана на багатій джерельній базі та містить цінний етнографічний матеріал. 5 з 22 розділів книги присвячено питанням етнографії. Зокрема це такі розділи як «Народ, його характер, одяг, звичаї, вірування і перекази», «Пісні», «Сучасний побут», «Господарство власників і волощан» та ін. Дослідник детально описав чоловічий та жіночий, буденний та святковий одяг населення Київщини. Окрім цього подав опис козацького одягу XVIII ст. (жупан з вузьким коміром, широкі шаровари, шкіряний пояс, порохівниця, ніж, пістоль). Однак значно більше уваги автор приділяв питанням духовної культури українців, описував звичаї та обряди річного календаря (різдвяні свята, веснянки, свято Івана Купайла тощо).

Окрім цього Е. Руліковський наводить у книзі велику кількість народних пісень, зокрема 35 весільних (серед них пісні, що співалися при заручинах, при випіканні короваю, після вінця та ін.), 15 чумацьких пісень. У наступній праці «Zapiski etnograficzne z Ukrainy» автор ретельно досліджував народні перекази, замовляння, звичаї та обряди. Окрім народних вірувань, пов'язаних 3 надприродними явищами автор, хоч і в меншій мірі, але описує сімейні звичаї та обряди українців [2, с. 61-64].

Ще один польський етнографр, дослідник традицій і побуту українського народу Антоні Марцінковський (псевдонім Антон Новосельський) (1823-1880) теж народився на Київщині. Автор опублікував у польськомовних часописах низку статей, присвячених українським святковим звичаям та обрядам. Ірунтовним дослідженням української етнографії стали 2 томи фольклорно-етнографрічних праць «Lud Ukraiński» у яких подано замовляння, казки, легенди, перекази, описи обрядів, зразки календарно- та родинно-обрядової поезії, соціально-побутові пісні, прислів'я, приказки, загадки. У першому томі детально описано календарну обрядовість Коляди та Купала, провідної неділі, Зелених свят, Рахманського Великодня, Маковія та подано народні перекази, пов'язані 3 цими святами, у окремих розділах досліджено сюжети народних казок. У другому томі розглянуто легенди і перекази про чародійство, народні скарби, уявлення про птахів і звірів, а також подано прислів'я, приказки та загадки.

Також автор подає відомості з народної медицини. Окрім різноманітних замовлянь населення широко використовувало лікарські властивості багатьох дикорослих і городніх рослин. А. Марцінковським подано 40 назв лікарських рослин та пояснення які хвороби вони лікують [12]. 
Продовженням теми дослідження народної медицини українщів стала робота відомого польського етнографра, лікаря за фрахом Юліана Талько-Гринцевича (1850-1936). У 1876 р., після закінчення університету, як практикуючий лікар Юліан Талько-Грицевич приїздить до Звенигородки і 3 перервами на наукові вакації мешкав тут до 1890 р. В містечку Рижанівці на Звенигородщині за участі лікаря у 1894 р. було відкрито Великий Рижанійвський курган, у дослідженні якого Талько-Грицевич брав активну участь.

Окрім заняття медичною справою та археологічними розвідками Ю. Талько-Гринцевич організував роботу зі збирання відомостей про народні знання у галузі медицини. Підсумком цієї чотирнадцятирічної праці стала поява 1893 р. у Кракові праці «Zarysy lecznictwa ludowego na Rusi południowej». Для збирання польового матеріалу дослідник залучив 15 помічників, які в різних місцях збирали свідчення населення. Джерельна база нарисів загалом нараховує 118 позицій, із них близько 50-ти - це матеріали, опубліковані впродовж XIX ст. у польськомовних виданнях у Львові, Варшаві, Кракові, Познані, Вільно. Етнографічну цінність праці посилюе те, що у ній використано більше трьохсот зразків українського магічно-сакрального фольклору, серед яких у жанровому відношенні переважають замовляння, примовки, заклинання, а також фольклорні молитви, чисельність яких становить понад п'ятдесят одиниць. Близько третини текстів дослідник перепублікував з інших джерел, посилання на які подано у праці. Решту фольклорних матеріалів вченому допомогли зі- брати кореспонденти, які проживали в різних історико-етнографрічних регіонах (Звенигородщина, Поділля, Східна Галичина, Волинь, Полтавщина, Херсонщина, Крим та Литва). Серед зібраних текстів значна частина автентичних усних молитовних зразків. Окрім цього Ю. Талько-Гринцевич висловив чимало цікавих думок i подав коментарі про український магічно-сакральний фольклор [3].

Серед активних збирачів етнографічного матеріалу з території Центральної України дослідники виокремлюють ім'я Юзефи Мошинської. Вона збирала звичаї та обряди населення Білоцерківського, Таращанського та Васильківського повітів Київщини. Завдячуючи праці дослідниці зібрано багато матеріалу щодо весільного обряду українців, зокрема 60 текстів весільних пісень. Інша стаття авторки містила детальний опис святкування Івана Купайла в околицях Білої Церкви. Дослідниця записала купальські ігри та пісні з 17 сіл. Також нею опубліковано 36 українських народних казок та 156 загадок з відгадками [2, с. 128].

Висновки. Таким чином, впродовж XIX ст. значний внесок у етнографічне дослідження Центральної України здійснили польські етнографри, письменники та громадські діячі. Не аналізуючи їхню ощінку українсько-польських взаємин та погляди на історичне минуле двох народів зазначимо, що польськими дослідниками зібрано та опубліковано великий масив першоджерельного фольклорного і етнографрічного матеріалу, що й досі зберігає своє важливе значення для науки про усну традиційну культуру українців.

\section{Список літератури:}

1. Антонюк-Кисіль В. Михайло Грабовський як дослідник історії України. Наукові праці історичного фбакультету Запорізького національного університету. 2010. Вип. ХХІХ. С. 277-281.

2. Болтарович 3. Україна в дослідженнях польських етнографрів XIX ст. Київ, 1976. 137 с.

3. Гунчик I. Українські фольклорні молитви в антропологічному дослідженні Ю. Талька-Гринцевича «Zагуsy Lechnictwa ludowegona Rusi Południowej». Народознавчі зошити. 2015. № 1(121). C. 238-243.

4. Гриневич Т. Проблематика історії України у творчості Северина Гощинського. URL: http://ena.lp.edu.ua:8080/ bitstream/ntb/15844/1/102-Hrynevych-224.pdf (дата звернення: 12.12.2020).

5. Дзира Я. ДОЛЕНІА-ХОДАКОВСЬКИЙ Зоріан URL: http://www.history.org.ua/?termin=Dolenga_Khodakovsky_Zm (дата звернення: 10.12.2020).

6. Пархета Л. Северин Гощинський (До 195-річчя від дня народження). Уманська зоря. 1996. 30 жовтня.

7. Пилипчук С. «Іоан Предтеча слов'янської археології і фольклористики»: Зоріан Доленга-Ходаковський в оцінці Івана Франка. Прикарпатський вісник НТШ. Слово. 2015. № 2. С. 422-428.

8. Сапеляк О. Етнографічні студії в Науковому Товаристві ім. Шевченка (1898-1939 рр.). Львів : Місіонер, 2000. 208 c.

9. Старенький I. Польський поет, який писав про Поділля. URL: https://klyuch.com.ua/articles/history/polskyypoet-yakyy-pysav-pro-podillya/ (дата звернення: 10.12.2020).

10. Талько-Гринцевич Ю. Нариси народного цілительства Південної Русі. Тернопіль : Навчальна книга - Богдан, 2019. $576 \mathrm{c}$.

11. Франко І. Додаткові томи до зібрання творів у 50-и томах. Київ : Наукова думка, 2010. Т. 54. С. $259-271$.

12. Шалак О. Український фольклор Поділля у вивченні Антонія Новосельського: методика комплексного дослідження. Мандрівець. 2014. № 3. С. 32-35.

13. Юревич М. Тема Коліївщини в польській літературі до появи шевченкових «Гайдамаків». Шевченкознавчі студіï. 2008. Вип. 10. С. 176-183.

\section{References:}

1. Antoniuk-Kysil V. (2010) Mykhailo Hrabovskyi yak doslidnyk istorii Ukrainy. Naukovi pratsi istorychnoho fakultetu Zaporizkoho natsionalnoho universytetu - Scientific works of the historical department of Zaporizhia National University, vol. XXIX, pp. 277-281. (in Ukrainian)

2. Boltarovych Z. (1976) Ukraina v doslidzhenniakh polskykh etnohrafiv XIX st. Kyiv. (in Ukrainian)

3. Hunchyk I. (2015) Ukrainski folklorni molytvy v antropolohichnomu doslidzhenni Yu. Talka-Hryntsevycha «Zarysy Lechnictwa ludowegona Rusi Południowej». Narodoznavchi zoshyty - ethnographic notebooks, no. 1(121), pp. 238-243 (in Ukrainian)

4. Hrynevych T. Problematyka istorii Ukrainy u tvorchosti Severyna Hoshchynskoho. URL: http://ena.lp.edu.ua: 8080/bitstream/ntb/15844/1/102-Hrynevych-224.pdf (accessed 12 December 2020). (in Ukrainian) 
5. Dzyra Ya. DOLENGA-KhODAKOVSKYI Zorian. URL: http://www.history.org.ua/?termin=Dolenga_Khodakovsky_Zm (accessed 10 December 2020). (in Ukrainian)

6. Parkheta L. (1996) Severyn Hoshchynskyi (Do 195-richchia vid dnia narodzhennia). Umanska zoria - Uman star. 30 zhovtnia. (in Ukrainian)

7. Pylypchuk S. (2015) «Ioan Predtecha slov'ianskoi arkheolohii i folklorystyky»: Zorian Dolenha-Khodakovskyi v otsintsi Ivana Franka. Prykarpatskyi visnyk NTSh. Slovo. - Prykarpattya Bulletin of NTSh. Word, no. 2, pp. 422-428. (in Ukrainian)

8. Sapeliak O. (2000) Etnohrafichni studii v Naukovomu Tovarystvi im. Shevchenka (1898-1939 rr.). Lviv: Misioner. (in Ukrainian)

9. Starenkyi I. Polskyi poet, yakyi pysav pro Podillia. URL: https://klyuch.com.ua/articles/history/polskyy-poetyakyy-pysav-pro-podillya/ (accessed 10 December 2020). (in Ukrainian)

10. Talko-Hryntsevych Yu. (2019) Narysy narodnoho tsilytelstva Pivdennoi Rusi. Ternopil: Navchalna knyha Bohdan. (in Ukrainian)

11. Franko I. (2010) Dodatkovi tomy do zibrannia tvoriv u 50-y tomakh. Kyiv: Naukova dumka. (in Ukrainian)

12. Shalak O. (2014). Ukrainskyi folklor Podillia u vyvchenni Antoniia Novoselskoho: metodyka kompleksnoho doslidzhennia. Mandrivets - traveler, no. 3, pp. 32-35. (in Ukrainian)

13. Yurevych M. (2008) Tema koliivshchyny v polskii literaturi do poiavy shevchenkovykh "Haidamakiv». Shevchenkoznavchi studii - Shevchenko studies, vol. 10, pp. 176-183. (in Ukrainian) 